\title{
Best Practice Model with BPM Approach in the Determination of Genealogical Links
}

\author{
Danilo Alberto Chávez Espíritu \\ National Registry of Identification and Civil Status-RENIEC \\ chavez.danilo@gmail.com
}

\begin{abstract}
Genealogy is of interest to people seeking to know their ancestors, and family ties require special attention for the meaning it represents. The techniques to process the data require good practices to manage large databases, which would not be possible without a model of best practices that is associated with the process to obtain a good link, allowing stories to be exchanged, since the computer systems Existing for community genealogy offer partial solutions for not having all the necessary information. This paper reviews a series of systems in organizations that manage large databases, such as those of the financial systems and others to formulate good practices under a BPM approach in a model to determine the best relationship of genealogical links, since the best practices are relevant to adapt them to the process of improvement, the evaluation of the integrated model of good practices with a BPM approach, in determining the genealogical links of the Peruvian identification registry will improve corporate management in the efficiency of the environmental component of organizations.
\end{abstract}

Keywords: Genealogy, BPM, best practices process

\section{Introduction}

According to Rodriguez, C. (2020), genealogy, has a history so remote, of interest to people seeking to know their ancestors, however, family ties allow us to resolve a series of problematic situations that we live through daily and that require special attention to fix it. It also tells us that it is possible to use Artificial Intelligence techniques with algorithms that quickly process data from large databases, which, but all this would not be possible without a model of good practices that is associated with the process to obtain a good result. Computer technology can help strengthen family ties by allowing them to resume contact and exchange stories, as existing 
computer systems for community genealogy offer partial solutions because they do not have all the information they need but are valuable. The thesis reviews a series of existing systems whose designs are relevant to the design of an online community for family stories. The solutions they offer only partially coincide with the objective of implementing this thesis, but useful ideas can be obtained by analyzing them and improving their basic design. People, places and time are the main indexes that will be used to organize and navigate the contributed materials. by community members. Appropriate representation and interfaces must be used to store and access materials through each of these keys. These three keys are cited by oral historians and autobiographical memory researchers as the main indexes used to store and access memories and stories. The effectiveness and power of community building tools can be increased through appropriate representation and accessibility of this information. Creating an online community for family history and genealogy involves a review of the genealogical business from a systems analysis perspective. Having an online community for the family Members who participate in telling stories about their shared past do not just grant the benefits mentioned above to the participants. It also drastically and advantageously alters genealogical research from a systems analysis perspective. The standard model for genealogical research implies that a single researcher gathers all the evidence and processes it to provide participants with a single final document. With an online family storytelling community, all members of a family can continually and openly contribute to building a mosaic made up of their common past. What people seek is to discover, investigating the history of their family, the answer lies in the benefits that are granted both by the process and by its result of collaborating as an active participant who contribute with their own narratives, and acting from the narratives. counted by others. Information in a family history project flows through family stories, that is, stories told by family members who talk about their shared past. The benefits of learning about the shared past are as abundant and numerous as the benefits of telling others about it. Family storytelling has benefits for both the teller and its audience. The act of listening and learning from stories brings the benefits of identity, orientation, and enrichment to the audience; the act of storytelling brings the benefits of consistency, generativity, and resulting human connections to the teller.

\section{Background}

How to verify the identity of the citizen based on the identification records? How to determine the citizen's uplinks based on identification and marital status records? How to process citizen information based on heuristic search algorithms? 
The determination of the genealogical links of the citizens is justified in the need to know their ancestral history with an important effect in the different fields that go from discovering the origin and relationship of cultures to its social, cultural, health, education, and social implications. security etc. (Rodriguez, 2020) In education it is important to reinforce the concept of historical time or the different family models currently existing in our society, and despite the fact that genealogy continues to be a very useful tool and little used by the large amount of information that accumulates over time we can consider its justification in the following ways. The study is important, because the integrated model of good practices with a BPM approach will allow the organization to optimize data management for the good relationship of the data, the result of which will allow organizations to maintain sustainability over time, also allowing improvement in its productivity and improvement in its institutional image at national and international level, and the results of the study will directly benefit society, the environment, collaborators, suppliers and customers of the organization. Reason why if these are not managed through an integrated model of good practices with a BPM approach, they will not be able to be competitive and efficient in the globalized market of the present millennium, since the trend and the various interest groups demand the highest precision. and efficiency in its organizational behavior, consequently, the innovative nature of this research work can be recorded, thus complying with one of the main requirements of all scientific research. According to the stated objectives, the paper has as general task the formulation, development of an integrated model of good practices with a BPM approach in optimizing the management of social responsibility of organizations, therefore, this methodology allows to develop a development standard New in the management of social responsibility, in order to improve its management through good business practices, and also to improve its competitiveness at the national and international level, but always ensuring its social environment and the well-being of all its stakeholders.

\section{Main concepts}

ISO 26000 Standard Fig 1 facilitates understanding, action and communication between organizations towards sustainability, based on 7 fundamental subjects that are: Organizational governance, human rights, labor practices, the environment, fair operating practices, consumer affairs and active participation in community development. (NTP / IEC- ISO 26000: 2010). In this sense, in Figure No. 2 of this document, we present the principles of ISO 26000. 


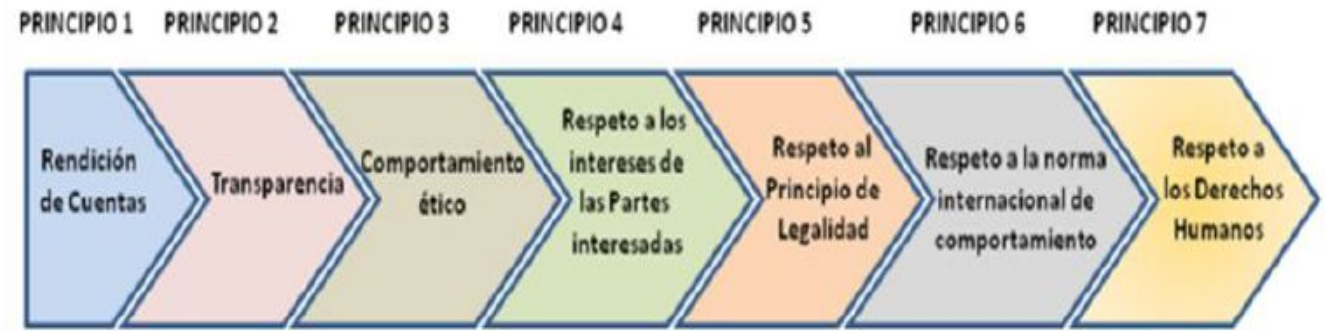

Figure 1: Principles of ISO 26000: 2010

Should be noted, ISO 26000 is an international standard that offers a guide on Social Responsibility, it is designed to be used by any type of organization; In this sense, the International Organization for Standardization, developed this undertaking with the aim of encouraging organizations to operate in a responsible manner and consistent with its principles and values, and go beyond the mere legal compliance of the State. If we implement an integrated model of best business practices with a BPM approach, then it would be possible to optimize the management of corporate social responsibility of the organizations attached to the Lima Stock Exchange In the following table 1 is shown the operationalization of the independent and dependent variables of the present study.

Table 1 Variable operationalization

\begin{tabular}{|c|c|c|c|}
\hline Variables & Dimensions & Indicators & Instruments \\
\hline $\begin{array}{l}\text { Independiente: } \\
\mathrm{X} 1 \text { : Best practices }\end{array}$ & $\begin{array}{ll}\text { - } & \text { ISO } 26000 \text { standard } \\
\text { - Global Reporting } \\
\text { Initiative - GRI } \\
\text { - Principles of the } \\
\text { Global Compact } \\
\text { BPM }\end{array}$ & $\begin{array}{l}\text { - } \quad \text { BPM application level } \\
\text { Level of integration and } \\
\text { implementation of good } \\
\text { business practices }\end{array}$ & Survey Form \\
\hline $\begin{array}{l}\text { Dependiente: } \\
\text { Y1: Manage }\end{array}$ & $\begin{array}{ll}\text { - } & \text { Corporate ethical } \\
\text { component } \\
\text { - } & \text { Economic component } \\
\text { - } & \text { Social component } \\
\text { - } & \text { Environmental } \\
\text { component }\end{array}$ & 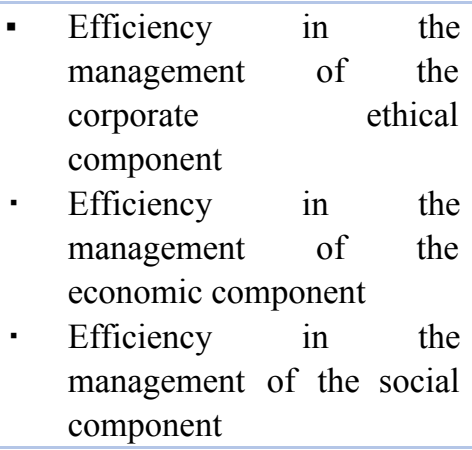 & $\begin{array}{l}\text { Guide for } \\
\text { preparing a } \\
\text { sustainability } \\
\text { report - GRI }\end{array}$ \\
\hline
\end{tabular}




\begin{tabular}{|l|l|l|l|}
\hline & $\begin{array}{ll}\text { Efficiency in the } \\
\text { management of the } \\
\text { environmental component } 1\end{array}$
\end{tabular} \mid

\section{Methodology}

For a long time the scientific method has given excellent results for the development of research, however, as we advance this new millennium, we can only be sure that the current technological turbulence and prospecting for the future will challenge our ability to solve problems and modify the fundamental structures on which the development of humanity has been based. (Pineda, 1996). The Research Level is Descriptive, which seeks to select a series of questions and measure each one independently, in order to describe what is investigated. Likewise, according to the nature of the study, it becomes an Explanatory investigation, since explanatory studies are structured and determine the causes of phenomena, generate a sense of understanding. The research method is framed according to the type of analytical research thesis, since the different topics will be analyzed extensively through their corresponding variables, which will allow us to reach valuable conclusions to test the hypothesis of the work; at the same time synthesized conclusions will be reached; In addition, the present study is framed by a deductive method which will allow to infer valid ideas, concepts, theories and conclusions, strictly for the organizations in this sense, to overcome the deductive method it is related to the contrast, presented a new idea provisionally, be it an anticipation, a hypothesis, a theoretical system or whatever you want, conclusions are drawn from it by means of a logical deduction; these conclusions are compared with each other and with other relevant statements (Popper, 1997). Therefore, the hypothetical deductive method presents its hypotheses based on laws or theories, in order to verify or refute them, before reality, applying in the hypothesis test; Under this concept and due to the nature of the research, an integrated model of good business practices is proposed, framed in the optimization of management. For responding appropriately to the nature and type of work carried out, the quasi-experimental design according to Valderrama (2014) "where an independent variable is deliberately manipulated to observe its effects on the dependent variable, allows the formation of control groups and experimental, using the randomization of its members "(p. 176-177). In this sense, according to the research objective, the association of the variables is intended to be demonstrated through the application of the Xi2 statistical method of independence. We also agree with Palomino et al. (2015) who states about quasi-experimental studies "procedures are used to manipulate the independent variable and measure what happens in the dependent variable, and then observe whether or not the expected variation in the dependent variable occurs when 
manipulating the dependent variable" (p.131-132). For our study, a statistical method will be applied that allows determining the presence or absence of association of the variables: Independent $(\mathrm{X})$ called Good Business Practices and the Dependent (Y) named Corporate Social Responsibility Management, two variables submitted to the present investigation, therefore, the hypothesis testing strategy is based on a general model shown in fig 2 .

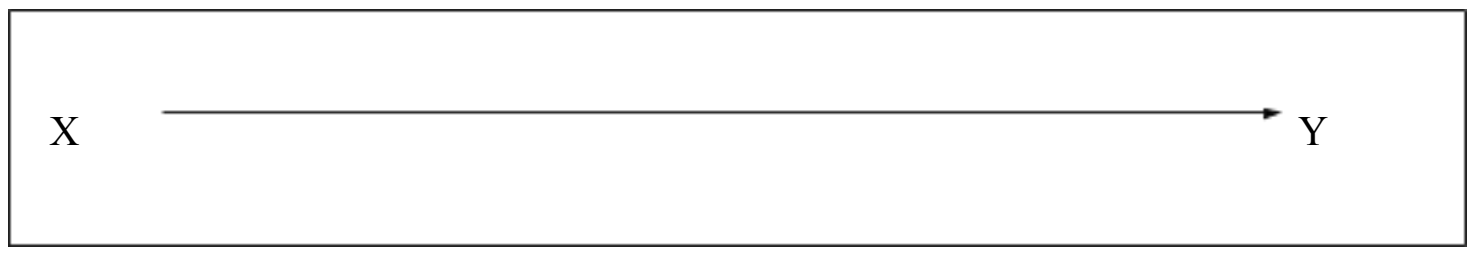

Figure 2 Relation between variables

The chi-square distribution is a non-parametric statistical test that is used for hypothesis testing, according to Webster, A. (1998) "non-parametric tests are statistical procedures that can be used to test hypotheses when it is not possible to fix no assumption about population parameters or distributions "(p. 836). In this sense, the X2 test consists of tests of goodness of fit and tests of independence. Therefore, for the hypothesis test according to the objective of the present investigation, we will apply the Xi2 of independence, because it is a tool that allows us to check the independence of categorical variables; and it facilitates the analysis of two factors with the purpose of determining the existence or not of a relationship between the variables. To do this, cross tabulation or contingency tables are applied and / or used.

\section{Integral model}

The integrated model of good business practices with a BPM approach for the optimization of corporate social responsibility management in organizations attached to the Lima Stock Exchange; It is also necessary to indicate that there are investigations that have left some classifications of sustainability reporting standards and norms as a strategy of continuous and competitive improvement for organizations; also taking into account the management of corporate social responsibility in the organizations of Peru, it is definitely incipient; In this sense, the integration and use of tools that solve the problems and needs of the organizations in this study, in addition to indicating that risk management is not developed appropriately in these organizations, since each of them has different characteristics to be taken into account, and when choosing solutions and sustainability reporting standards. Within this framework, there are various standards, norms and methodologies that are focused on the continuous improvement of organizations from 
their different corporate social responsibility approaches; therefore, this chapter proposes the application of different proposals and approaches found in the literature review, taking full advantage of the advantages and benefits of each one. Therefore, in Figure $\mathrm{xx}$, of this document we present the graphic representation of the integrated model of good business practices with a BPM approach, in the optimization of management in organizations. 
Gyancity Journal of Engineering and Technology, Vol.6, No.1, pp. 1-11, January 2020

ISSN: 2456-0065 DOI: 10.21058/gjet.2020.61005

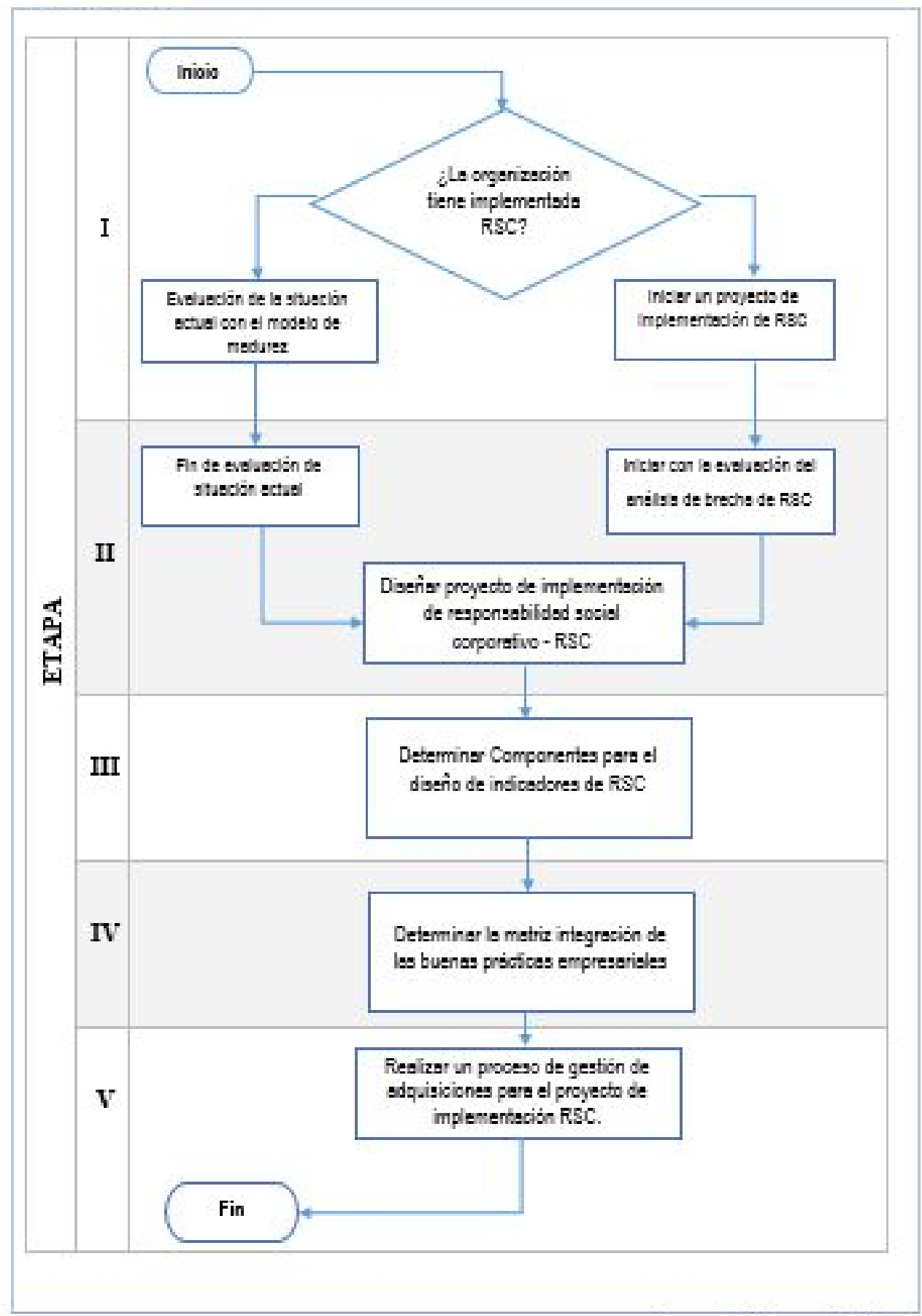

Figure 3: Graphic representation of the integrated model of good business practices with a BPM approach. 
Gyancity Journal of Engineering and Technology,

Vol.6, No.1, pp. 1-11, January 2020

ISSN: 2456-0065 DOI: 10.21058/gjet.2020.61005

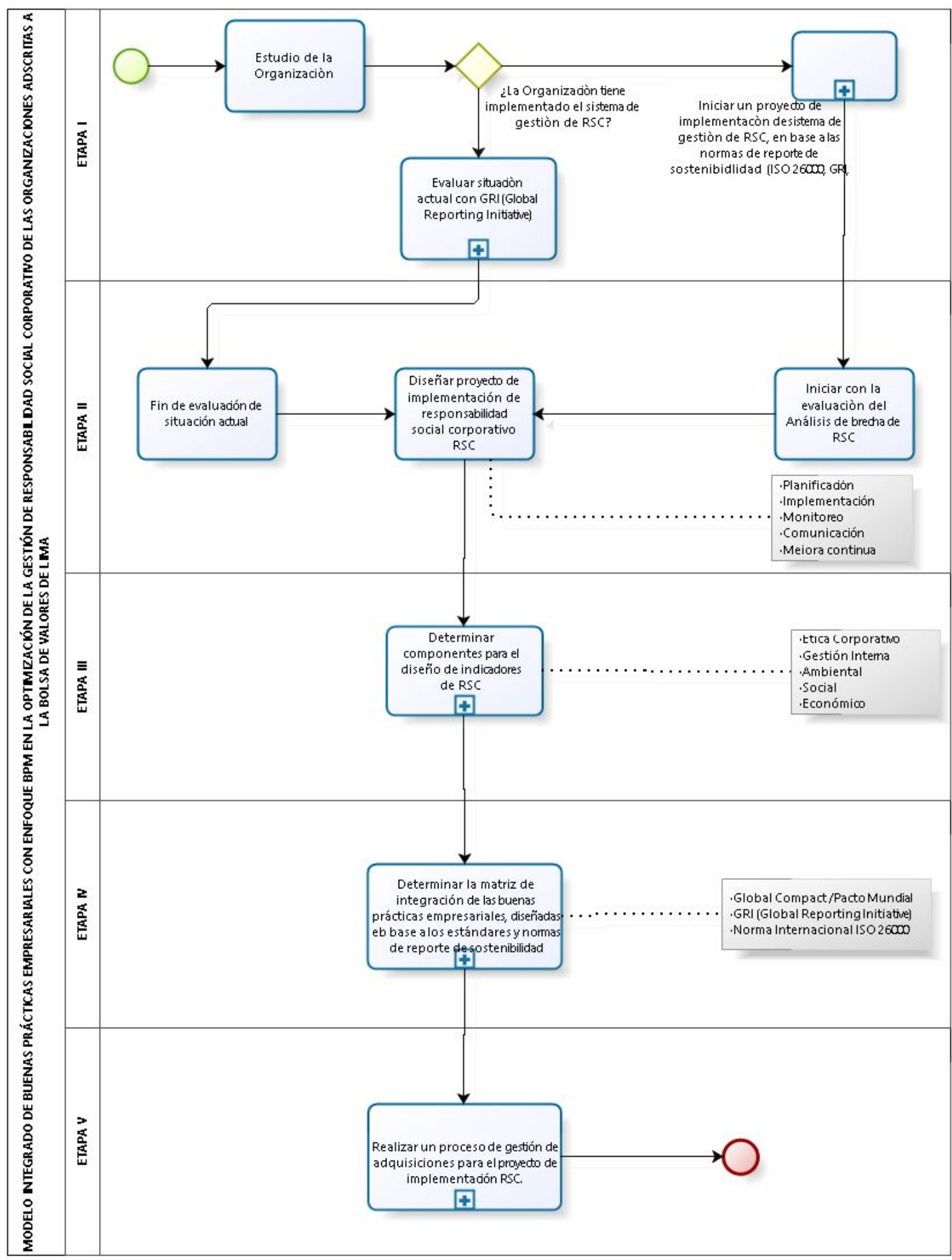

Figure 4: BMPN representation of the integrated model of good business practices with a BPM approachNext, the model conceptual and detailed way the BMPN 
representation of the integrated model of good business practices in the optimization of corporate social responsibility management in organizations.

\section{Results}

The testing of research hypotheses, in the context of inferential statistics, is a proposition regarding one or more parameters, and what the researcher develops through the hypothesis test, facilitates the establishment of inferences from the sample analyzed towards the population of origin; In particular, the Chi-square test of independence was applied to the research.

H1: The implementation of an integrated model of good business practices with a BPM approach, optimizes the management of the genealogical links of the Peruvian identification registry. The evaluation of the integrated model of good practices with a BPM approach, in determining the genealogical links of the Peruvian identification registry, will improve corporate management in the efficiency of the environmental component of organizations, as shown by the results. In table $\mathrm{x}$, it presents the results obtained on contracting the general hypothesis, and its respective analysis.

Table $N^{\circ}$ 22: Chi-square tests of the General Hypothesis

\begin{tabular}{|c|c|c|c|c|c|}
\hline & Value & $\mathrm{df}$ & $\begin{array}{c}\text { Asymptotic } \\
\text { significance } \\
\text { (bilateral) }\end{array}$ & $\begin{array}{c}\text { Exact significance } \\
\text { (bilateral) }\end{array}$ & $\begin{array}{c}\text { Exact significance } \\
\text { (unilateral) }\end{array}$ \\
\hline Pearson's Chi-square & $44,321^{\mathrm{a}}$ & 1 &, 000 & & \\
\hline Continuity correction(b) & 40,583 & 1 &, 000 & & \\
\hline Likelihood ratio & 35,329 & 1 &, 000 & & \\
\hline Fisher's exact test & & & &, 000 &, 000 \\
\hline $\begin{array}{l}\text { Linear by linear } \\
\text { association }\end{array}$ & 44,044 & 1 &, 000 & & \\
\hline $\mathrm{N}$ of valid cases & 160 & & & & \\
\hline
\end{tabular}

a. 1 cells $(25.0 \%)$ have expected a count less than 5 . The minimum expected count is 4.40 .

b. It has only been calculated for a $2 \times 2$ table

\section{Conclusion}

The evaluation of the integrated model of good practices with a BPM approach, in determining the genealogical links of the Peruvian identification registry, will improve corporate management in the efficiency of the environmental component of organizations, as shown by the results. 


\section{References}

Acuerdo Nacional, Un Futuro para Todas. (2015), recuperado el 04 de octubre del 2017: http://acuerdonacional.pe/wp-content/uploads/2014/07/LibroV2014_1.pdf

Beltrán, J., Carmona, M., Carrasco, R. Rivas, M. y Tejedor, F. (2012). Guía para una gestión basada en procesos, Instituto Andaluz de Tecnología- IAT, España, recuperado el 2 de octubre del 2017:

https://www.oviedo.es/documents/12103/f8e7f4c1-a7ba-4fb5-87d7-c95335 c79b22

Bonilla, E. \& Díaz, B. \& Kleeberg, F. \& Noriega, M. (2010). Mejora Continua de los Procesos, Fondo Editorial, Universidad de Lima, Lima-Perú

Bravo, J. (2011). Gestión del Procesos, Alineados con las Estrategias. Editorial Evolución S.A. Santiago de Chile

Díaz, F. (2008). Gestión de procesos de negocio BPM (Business Process

Management), TICs y crecimiento empresarial, Univ. Empresa, Bogotá, Recuperado el 10 de enero del 2018: https://dialnet.unirioja.es/descarga/articulo/5096778.pdf

Eimer, P. \& Miller, J. (2002). Guía de Buenas Prácticas de Gestión Empresarial para Pequeñas y Medianas Empresas, recuperado el 09 de octubre del 2017: http://www.iadsargentina.org/pdf/ANEXO\%20IV\%20-\%20Guia\%20BGE $\% 20(1)$.pdf

Flores, E. (2010). Gestión de la Calidad, Faculta de Ciencias Ecnomicas y Comerciales - Universidad Sedes Sapientae, Lima - Perú

Francisco, B. (2015). Carta Encíclica Laudato SI, sobre el Cuidado de la Casa Común, Roma-Italia

Friedman, M. (1970). The Social Responsibility of Business is to Increase its Profits, New York Times.

Idecopi (2016). Reconocimiento de las Buenas Prácticas Empresariales, recuperado el 09 de octubre del 2017:

https://www.indecopi.gob.pe/documents/51084/126949/CompendioConcur soPrimeroLosClientes/781abb09-3984-4e3f-bf64-ddf4456f0e6c

Rodríguez, C, Lezama, P.,Kaseng, F. Chavez, D.(2020). Bayesian Model to Determine Genealogical Links of Family Descendants. Test Engineering and Management.

Rodríguez, F (2011). Buenas prácticas e indicadores de RSE de empresas del Eticentre. Mallorca-España, Recuperado el 11 de enero del 2018: http://ww2.eticentre.org/documents/bbpp-indicadors-rse-web-es.pdf. 